\title{
Orientação à queixa escolar: uma nova prática em psicologia clínica
}

\author{
Psychological guidance of school complaints: a new pratice in clinical Psychology
}

SOUZA, B. de P. (Org.). (2007). Orientação à queixa escolar. São Paulo: Casa do Psicólogo, 419 p.

"Orientação à queixa escolar" destoa das publicações psiquiatrizantes que abundam no mercado editorial da psicologia, constituindo-se a partir do encontro de várias perspectivas: a crítica à patologização da queixa escolar e às políticas públicas de educação; as consultas terapêuticas winnicottianas; o materialismo histórico; a esquizoanálise e a psicologia institucional. Contra o conformismo que parasita as relações entre psicologia e educação desde os anos 1920, mas vem se rompendo nos últimos 30 anos de psicologia brasileira, faz-nos ver que uma atuação, mesmo clínica, em psicologia escolar, não precisa ser apolítica nem tecnicamente distante da escola.

O espaço clínico é tratado como catalisador para que a compreensão dos funcionamentos institucionais propicie a criação de uma nova prática psicológica. O profissional surge como orientador, como disparador de possibilidades de mudança mesmo em situações escolares adversas a um desenvolvimento humano emancipador. O livro sintetiza-nos uma das propostas teórico-práticas criadas no Serviço de Orientação à Queixa Escolar do Instituto de Psicologia da Universidade de São Paulo (SePE-IPUSP), através de 18 capítulos. Eles são redigidos, na sua maioria, pela própria Beatriz de Paula Souza (psicóloga do referido serviço), por ex-alunos ligados ao SePE-IPUSP e docentes do IPUSP.

Reconhecendo os meandros da construção da queixa, o livro procura superar o excesso de encaminhamentos para a psicoterapia originários da clínica da queixa escolar. Também, divulga uma prática que diminuiu consideravelmente o percentual de desistências $(55 \%)$ subsequente ao psicodiagnóstico tradicional da queixa escolar (e da assustadora proporção de $38 \%$ de famílias que abandonam o atendimento após as entrevistas iniciais). Os funcionamentos institucionais, os anseios e os problemas de comunicação entre os envolvidos na queixa são interpretados como as determinações mais próximas da queixa escolar, sem que haja o tradicional recuo investigativo às (reais, porém muito frequentemente inessenciais) minúcias da história psicomotora ou familiar do aluno e aos velhos laudos psicológicos que têm sido verdadeiros passaportes para a marginalização escolar/política de tantos brasileiros. B.P. Souza e os demais autores defendem, sim, um aprofundamento progressivo no conhecimento das camadas de poder da cena escolar. Ver a escola, os cadernos, conversar com os professores, proporcionar encontros entre famílias para o apoio frente a problemas semelhantes, conhecer os fundamentos da alfabetização e das teorias sobre o desenvolvimento do processo ensinoaprendizagem são tarefas importantíssimas para o novo clínico.

As intervenções procuram recuperar o desejo de estar na escola e avivar a confiança das crianças em sua capacidade de aprender e a dos adultos em educá-las, ambos relegados a segundo plano em benefício de ideias equivocadas que embaraçam a compreensão das múltiplas determinações do processo ensino-aprendizagem. É o caso da patologização da queixa escolar (via dislexia e déficit de atenção/hiperatividade) e das informações "trágicas", abelhudas e inconvenientes, que circulam no espaço escolar sobre a difícil vida das crianças e suas famílias. Mostrando a intimidade de várias escolas públicas paulistas, o livro procura romper com os excessos de criticismo dos psicólogos perante o trabalho dos professores, embora sem esquecer a violência com que estes, reproduzindo velhos discursos da sociedade brasileira, trazem, pela porta dos fundos aberta pela patologização, preconceitos de raça e classe social.

O capítulo de Kelly Sobral e Beatriz de Paula Souza mostra, no esquecimento kafkiano que envolve a populaçãoobjeto de queixa, o negativo das predileções da escola, consubstanciado na exclusão rotineira que ela promove: o "discurso queixoso" é mais frequente no sistema público estadual, recai mais sobre meninos que meninas e até a $4^{a}$ série do ensino fundamental (já que os alunos mais velhos, adolescentes, são "caso sério", convertido não em objeto de queixa escolar, mas em sujeitos atendidos por Conselhos Tutelares e programas socioeducativos). O livro aponta a carência de estatísticas estaduais e nacionais sobre o perfil da queixa escolar e o desempenho da escola pública, lacunas que dificultam tanto a pesquisa quanto a práxis política de psicólogos, professores e cidadãos interessados no assunto.

O texto de José Moura Gonçalves Filho enfoca as experiências de humilhação da população trabalhadora, apanhando os psicólogos em susto. Ou, para trocar uma letra: em "surto" teórico coletivo, caracterizado pela incapacidade generalizada de tomar contato com a realidade 
e praticar uma intervenção que supere preconceitos, conhecendo efetivamente o cotidiano da população atendida. Contribuindo para sanar essa ignorância, o livro produz um marco interpretativo capaz de auxiliar muito na compreensão de vários fenômenos que se agregam sob o rótulo de "queixa escolar" na clínica psicológica. Caso dos alunos "copistas" (que copiam textos, mas não sabem ler) e os atrasados/abandonados em classes massificadas, homogêneas. Damos, então, razão a Sérgio Leite, que, gramsciano, enxerga na escola um espaço em que ocorrem conflitos ideológicos nos quais a neutralidade é impossível. Pode-se concluir que as supramencionadas ignorâncias do psicólogo têm função na manutenção do status quo. Para quem está dentro ou fora da escola, esta torna-se região na qual toda interpretação é enunciada numa zona de tensão permanente, num espaço social em que emergem fenômenos às vezes pouco documentados. Eles exigem um olhar novo de todos os partícipes da vida escolar. Neste sentido, não há boa intervenção junto à queixa escolar sem a permanente produção de conhecimento do e para o coletivo escolar.
A comunicação entre posicionamento político nos níveis micro (o da interpretação teórico-prática de casos particulares) e macrossocial (a luta pela mudança das políticas públicas e dos fenômenos culturais causadores da queixa) consolida-se nas considerações finais de Beatriz de Paula Souza. A autora frisa a necessidade de que os psicólogos se integrem nas lutas por uma melhor qualidade de ensino. Uma ação que a própria autora empreende é a construção de redes de profissionais que compartilham o objetivo de construir novas práticas de atendimento psicológico às queixas escolares, práticas envolvidas com a crítica dos modelos medicalizantes de subjetividade através da compreensão social e histórica desta última, com a circulação de informações, pesquisas e discussões sobre as práticas e políticas relacionadas à psicologia escolar. Mas cremos que outras possibilidades de ação política podem ser inspiradas pelos escritos coligidos nesse excelente "Orientação à queixa escolar". 